\title{
ANALYSIS OF TERRORISM MOTIVATION DETERMINANTS
}

\author{
Krastyu KRASTEV \\ "Vasil Levski" National Military University, Veliko Tarnovo, Bulgaria \\ krustev_kr@abv.bg
}

\begin{abstract}
In its essence, terrorism is a human destructive activity and as such it is characterized by certain motives, needs, etc. It is important for the researchers to analyze in detail the needs that underlie normal human functioning and those that determine terrorism and integration into a terrorist organization. It is quite possible that such a research approach leads to the conclusion that they are not principally, qualitatively different, rather the needs of the terrorist are hypertrophied basic human needs, and the differences are quantitative. The current paper presents some results of the analyses of the main determinants of motivation for terrorism - the need for power; belonging, recognition and self-realization as undoubted motivators of terrorist activity, etc.
\end{abstract}

Keywords: terrorism, motivation, determinants, analysis

\section{Introduction}

There is a biblical truth about violence pronounced by St. Basil, according to which it stems from the human envy that is a consequence of human malice towards the well-being of the neighbor.

Why and under what circumstances does a person become a terrorist and resort to violence against other members of society? This is a question that is the focus of modern terrorist research.

The actions of terrorists, even political, nationalistic and "ideological", usually seem rational, thoughtful and wellprepared. That is why to find and detain criminals or potential terrorist is a very difficult task. It seems that there should be no doubts that before us are reasonable people who know their goals and are motivated by clear motives. [1]

However, how to combine the bright ideals and inhumane cruelty of terrorists, the height of their thoughts and the primitiveness of views and knowledge, the willingness to sacrifice themselves for the sake of people and the confidence in the admissibility of killing them in large numbers for the sake of the triumph of their intentions.

Therefore, the modern specialists underline that the impression of clarity of terrorist acts motives is very deceptive. [2] Like many other human acts, the motivation for terrorism is complex, multilevel and ambiguous. [3] The terrorism motives need to be distinguished depending on the species belonging to a specific criminal act. [4]

The main purpose of this research is to analyze the main determinants of terrorist motivation.

The object of the research is the motivation as a leading factor in human activity.

The research methodology includes some of the main scientific research methods dialectical and logical-semantic methods, system-structural and system-functional research approaches.

Of course the current paper doesn't claim to be exhaustive, but may facilitate further scientific research in this very sensitive scientific field. 
2. Analyzing the modern terrorism typology and motivation

According to the studies realized in 1998 by from Reich and by Harmon in 2001, it seems that there should be no doubts that in front of us are reasonable people who know their goals and are motivated by clear motives. [5,6,7]

Therefore, we can say that the impression of clarity of terrorist acts motives is very deceptive. Like many other human acts, the motivation for terrorism is complex, multilevel, and ambiguous; the motives themselves are largely subconscious and need to be distinguished depending on the species belonging to a specific criminal act.

\subsection{Tactical typology and individual motivation}

To start analysing the typology of the modern terrorism we will focus on the proposed tactical typology of terrorism presented in Fig. 1 [8]

The determinants of motivation for terrorism can be grouped into two main groups - individual and collective.

The individual terrorism motivation is driven by the combination of the following factors:

- intense grievances sense of crisis address a power imbalance;

- empower the disenfranchised combination of ideology and psychology;

- religious ideology has replaced revolutionary ideology

- most common domestic terrorists tend to be forward-looking to apocalyptic future

- international terrorists tend to be backward-looking, which lead to sense of grievance, humiliation, deprivation, or neglected duty etc. [9]

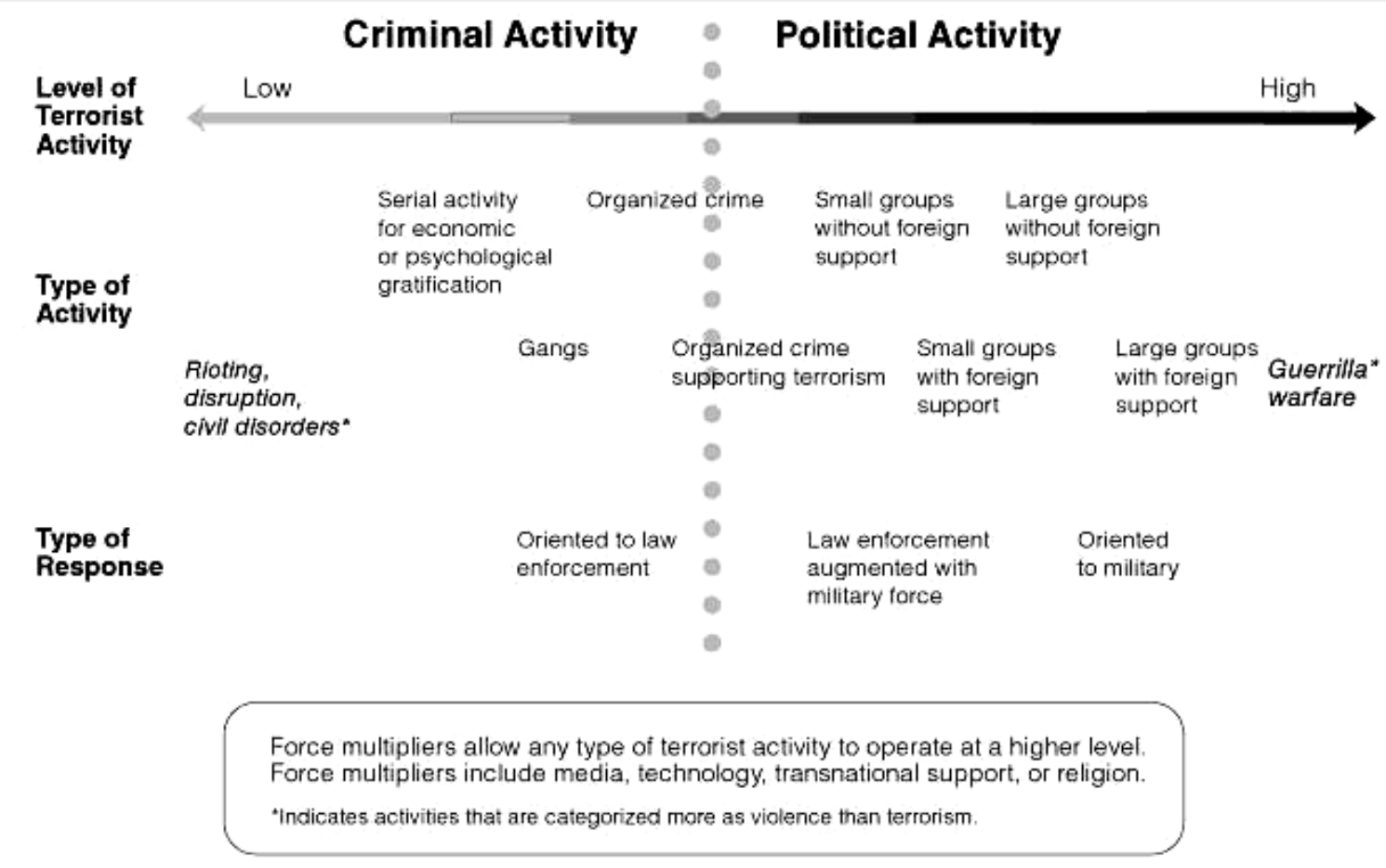

Figure 1: Tactical typology of terrorism

Individual terrorism motivation is characterized by its psychological and social dimensions; moral disengagement; displacement of responsibility; disregard 
for/distortion of consequences; dehumanization; moral justification etc.

Some scholars, Vityuk \& Efirov, underline the following motives of terrorism: selfaffirmation, self-identification, youth romance and heroism, giving its activity special significance, overcoming alienation, conformism, impersonality, standardization, marginality, satiety and possible selfish motives that can displace ideological ones or intertwine with them. [10]

There is a general perception that violent methods of terrorism resort to those who feel weak through other (legitimate) methods to oppose a more powerful majority than them. In other words, those perceived as weaker and less well-off members of society are likely to become terrorists, but this is a rather generalized view. Obviously there is a certain set of personality traits that are inherent to the terrorists' psychology.

Individual terrorism should be viewed as the act of violence that is an expression of an existential subjective protest by a particular, self-acting individual aimed at other members of society. Individual terrorism is most often determined by certain psychological traumas that precede the acts of violence.

Analyzing the socio-psychological motivation of terrorists, we also find other characteristics specific for them.

According to the specialists (Conway \&Siegelman,1978) the early socialization of the personality lies in the contradiction between the individual's research needs and his inadequate motor and cognitive abilities. [11]

Along with the various factors that encourage individual terrorism, other factors can also be identified that encourage individuals to disengage. These include disillusionment with violence, personal traumatic events, weariness, and a desire for normalcy.

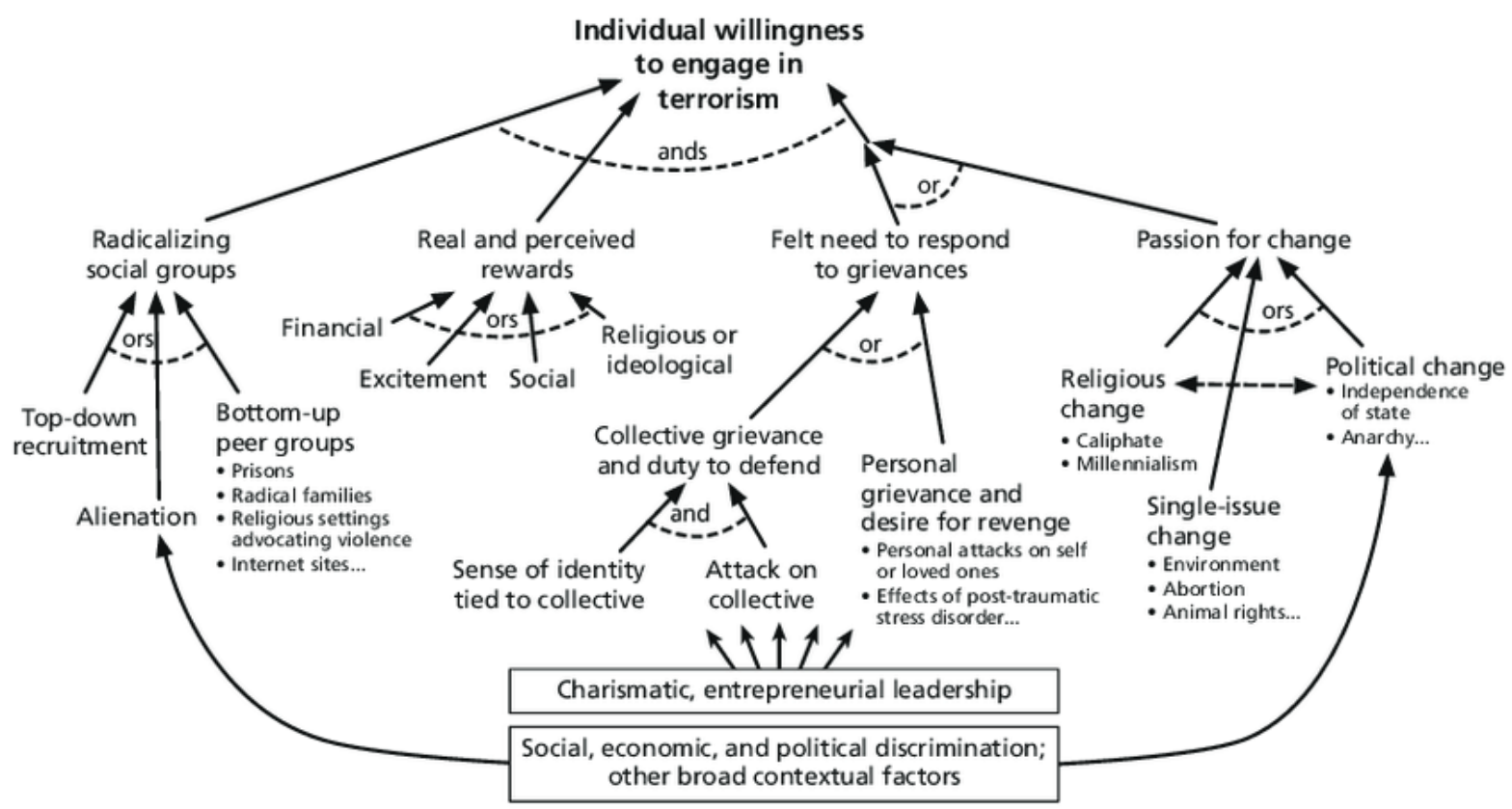

SOURCE: Adapted from Helmus (2009).

RAND OP296-4.2

Figure 2: Individual motivation determinants 
Similarly, a team from the Institute of Philosophical Research at the Bulgarian Academy of Sciences has defined the social profile of Islamic fundamentalist - feeling suppressed, repulsed by contemporary society, outraged, seeking help, gloomy, with vague perspectives, aggressive. [12]

\subsection{Collective motivation}

The motivation of modern terrorist organizations is ethno-nationalist, anarchist, religious or purely political. [13]

All terrorist organizations have an ideological rationale and a platform that distinguishes them from one another and defines the direction of their actions. What is characteristic for their ideological platforms is that they have extremely extremist and radical views aimed at changing the political system and public power in a society and, on the other hand, allowing the use of violence in the pursuit of the pursued goals. [14]

Terrorism is a symbiosis between the high degree of political motivation of terrorists and the low level of participation of the population of countries where they commit acts of violence. Small groups are involved in terrorist acts, and this distinguishes terrorism from national liberation movements. [15]

Having outlined the essential characteristics of modern terrorism and before we proceed to define this concept, we will address another problem that we consider to be extremely important. Not only in theoretical order but also in a purely practical nature it is important to give a scientifically based distinction between terrorism and organized crime. [16] The exact and definite distinction between them is necessary at a later stage to refine the legal competences of the different state bodies called upon to counter terrorism on the one hand and organized crime on the other. The targets of organized criminal groups are precisely selected and do not seek to achieve a colossal public effect, such as the emergence of the syndrome of the consequences of violence, as in terrorist acts.

\section{Criminal aspect of terrorist motivation}

It should be emphasized that while the violence of terrorists is driven by their hatred of the whole society and directed against this society, the violence of organized criminal groups is not so largescale. [17]

Another important element that is observed (but in various aspects) in terrorist organizations and organized crime groups is their attitude to the existing state power and form of government. The attitude of organized criminal groups to the existing state power (conditionally could be categorized as positive) can be seen as a means of achieving their goal, whereas the attitude of terrorist organizations to the existing state power and form of government can be regarded as an extreme negation, and their cardinal purpose is to destruct, destabilize or change the government.

From a legal point of view, terrorist activity is always a deliberate act. The motivation for doing so may be different. In most cases terrorists have the most extreme reactionary views and trends, the motives can be both purely political and religious-political, whereas ethno-nationalist (separatist) motives are varieties of political motivation. If the characteristic of the phenomenon is to be briefly outlined, terrorism is a violent crime motivated by political motives.

Most terrorist acts are mainly ordinary crimes that turn into terrorism only in connection with the motivation of the perpetrators. If their motives are to change seriously or destroy basic principles or pillars of statehood ... we face a terrorist threat. Such is the perception of the legislation of the European Union membercountries regulating the fight against terrorism. [18] 


\section{Terrorism motivation determinants implemented in REMM model}

The developed REMM model represents the process of Religious Extremism Manifestation. (Fig. 3)

For the purpose of our research we will implement the terrorism motivation determinants $-\mathbf{M}_{\mathbf{T}}$ in order to understand the importance of their influence.

The first independent variable $\mathbf{E}_{\mathbf{R E}}$ (Existence) represents the issue of ascertained existence of some extremist persons or groups in the region.

Second independent variable $\mathbf{C}_{\mathbf{R E}}$ (Capabilities) represents the capabilities of the existent religious extremist groups. It includes the level of the extremist's knowledge, their criminal or terrorist experience, financial support, weapons (small arms, explosives, etc.) and other sources needed for conducting terrorist acts. The third variable $\mathbf{I}_{\mathbf{R E}}$ (Intentions) is determined by the previous variables $\mathbf{E}_{\mathbf{R E}}$ (Existence) and $\mathbf{C}_{\mathbf{R E}}$ (Capabilities). It also includes the aim of the religious extremist group and the desired effects of the terrorist act.

$\mathbf{T}_{\mathbf{R E}}$ (Targets) is the last variable in the proposed model, which occurs in the presence of the other three variables and is in close dependence with the aim and desired effects of the terrorist act.

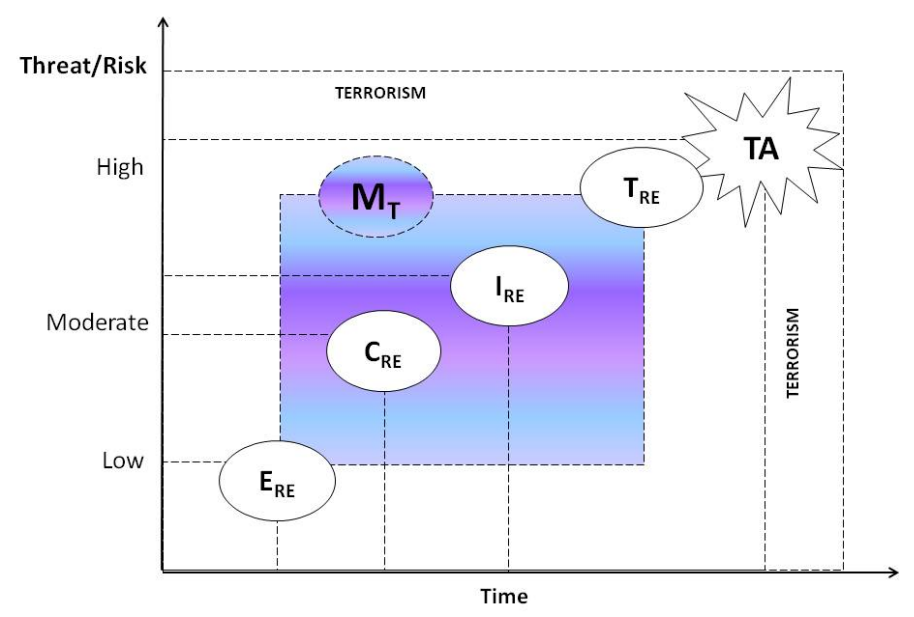

Figure 3: Terrorism motivation determinants in REMM model

\section{Analyzing the results}

The analysis of the $\mathbf{M}_{\mathbf{T}}$ determinant implementation shows that the motivation for terrorism appears after $\mathbf{E}_{\mathbf{R E}}$ and before $\mathbf{I}_{\mathbf{R E}}, \mathbf{C}_{\mathbf{R E}}$ and $\mathbf{T}_{\mathbf{R E}}$, which is logical in the proposed model. Taking it into consideration, we can conclude that the terrorism prevention is possible only before the terrorist act is conducted.

From this point of view, we would like to emphasize the importance of the interrelation between $\mathbf{M}_{\mathbf{T}}$ and $\mathbf{I}_{\mathbf{R E}}$ and $\mathbf{C}_{\mathbf{R E}}$ for the countering terrorism approaches. If the potential terrorist doesn't have a level of motivation that is high enough, it will be almost impossible for him / her to have some terrorist intention $\mathbf{I}_{\mathbf{R E}}$ and to develop the proper capabilities $\mathbf{C}_{\mathbf{R E}}$, as well as to select the target $\mathbf{T}_{\mathbf{R E}}$. Taking into account the degree of importance of motivation $\mathbf{M}_{\mathbf{T}}$ in the process of terrorism manifestations, it is possible to conclude that counterterrorism strategies and approaches should focus on influencing and reducing the level of motivation of those who are susceptible to terrorism. The motivation is the "key determinant" for success in countering terrorism efforts. 


\section{Conclusions}

In our view, in a purely socio-psychological aspect, and in order to arrive at spontaneous individual terrorism, it is necessary in the first place that the individual have a subjective perception in his / her mind that the society limits his / her self-realization as a whole.

Second, the existence of subjective beliefs in the individual's minds that:

- by legitimate means they can't fit into the society, which is why violence against society is a major way of protest and a means of self-realization;

- the presence of paranoid perceptions of society as an evil creature against which all means of combat must be used, including violence.

When considering the socio-psychological characteristics of the terrorist motivation, the logical question arises -"Is it possible for our society in crisis to give birth to potential terrorists".

Unfortunately, currently the answer is positive.

\section{References}

[1] Walzer M., Analysis of the morality of terrorism in Just and Unjust Wars, New York, pp. 197-206, 1977.

[2] Goldstein J., Aggression and Crimes of Violence, New York, 1975.

[3] Lichter R., A Psychopolitical Study of West German Male Radical Students, Comparative Politics, pp. 27- 48, 1979.

[4] Russell Ch.A. \& Miller H., Profile of a Terrorist, Terrorism-An International Journal, Gaithersburg, pp. 81-95, 1978.

[5] Al-Qaeda in the Arabian Peninsula: Shooting, Hostage Taking, Kidnapping Wave May/June 2004, Alexandria: Tempest Publishing, LLC, pp. 46-60, 2004

[6] Harmon C. C., Terrorism Today, Portland: Frank Cass Publishers, p.213, 2001.

[7] Reich W., ed., Origins of Terrorism: Psychologies, Ideologies, Theologies, States of Mind, rev. ed.,Washington: Woodrow Wilson Center Press, p.16, 1998.

[8] Desai R., Terrorism, An Educational Blog, June 1, 2013 (http://drrajivdesaimd.com/2013/06/01/terrorism/ accessed: 20.03.2018; 11:20)

[9] Forest J JF, Terrorist motivation, Combating Terrorism Centre at West Point, (http://slideplayer.com/slide/7397187/ accessed: 20.03.2018; 11:20)

[10] Vityuk V, Efirov S., Left oriented terrorism in the West: history and modernity. M., 1987, pp. 257-259.

[11] Conway R., J. Siegelman. Snapping: America's Epidemic of Sudden Personality Change. New York, 1978, p. 81-93.

[12] Slanikov I \& others, Philosophy of the Religion, Sofia, Publishing House, 2000, p.203.

[13] EUALEC, EU Terrorism Situation \& Trend Report (TE-SAT) 2017, European Union Agency for Law Enforcement Cooperation, Hague, 2017, p.4.

[14] "Introduction to Political Terrorism." Terrorism: Essential Primary Sources. Retrieved March 28, 2018 from Encyclopedia.com: http://www.encyclopedia.com/politics/energygovernment-and-defense-magazines/introduction-political-terrorism

[15] Grabovski P., Stohl M., Crime and terrorism, SAGE Publications Ltd, 2010, p.152.

[16] Martin G., Essentials of Terrorism, Concepts and Controversies, Ed.4, SAGE Publications Ltd, 2017, p.336.

[17] Kennedy-Pipe \& oth., Terrorism and Political Violence, SAGE Publications Ltd, 2015, p.328.

[18] European Union, The European Union's Policies on Counter-Terrorism. Relevance, Coherence and Effectiveness, (available at www.europarl.europa.eu/supportinganalyses), 2017. 